\title{
The Classical Debt: Greek Antiquity in an Era of Austerity
}

Review Number: 2145

Publish date: Thursday, 3 August, 2017

Author: Johana Hannink

ISBN: 9780674971547

Date of Publication: 2017

Price: $£ 23.95$

Pages: 352pp.

Publisher: Harvard University Press

Publisher url: http://www.hup.harvard.edu/catalog.php?isbn=9780674971547

Place of Publication: Cambridge

Reviewer: Helen Roche

At the height of the Greek financial crisis, reports from colleagues based in Athens painted a sorry picture of respectable citizens who had fallen upon hard times desperately rummaging in dustbins to supplement their dwindling larders. The statistics told an even grimmer story - between 2010 and 2011, suicide rates in Greece rose by 40 per cent.(1)

It was this utterly crass - if not horrific - mismatch between the genuine suffering which she observed whilst living in Greece, and the flippant and denigratory comments and cartoons comparing ancient and modern Greeks peddled by the world's media, which first led Johanna Hanink to explore the genesis and development of Europe's perennial obsession with the glories of the ancient Greek past. Her survey is therefore highly critical of contemporary 'Western' encomia of ancient Greece as the birthplace of all possible goods; she seeks instead to deconstruct such complacent and self-serving narratives, as well as posing a series of telling questions:

How much does the Western world continue to owe the Greek people for things that their ancestors did thousands of years ago? Is the idea that Greek antiquity is the root of the modern West just a mirage, or has Brexit proved that an admiration of ancient Greece is actually a stronger bond among Western nations, especially in Europe, than fragile modern political coalitions such as the European Union and NATO? Finally, if the 21 st century is proving that we are not all Greeks after all, then who are we? (pp. 7-8)

Hanink's self-proclaimed mission is to question that all-too-often uninterrogated narrative which claims, as Stephen Fry put it at a panel debate in 2012, that: '... no matter how much the sovereign debt crisis means they owe us ... we will never repay the debt that we owe Greece' (p. 5). Such pseudo-historical grandstanding has also been a feature of Greek negotiations with the EU; one Greek civil servant stated in the New York Times in February of that same year: '... we understand that things cannot remain the same ... but we gave the world democracy, and we expect the European Union to support us' (p. 6).

Since at least the Greek War of Independence, Greece has been caught up in a complex web of reciprocal debt-relations, both literal and symbolic. Citizens of Britain, France, Germany and America have frequently 
used 'an imagined stake in [Greece's] distant past to justify intervention in contemporary Greek affairs', often to the tune of staggeringly large loans, whilst simultaneously 'touting their "indebtedness" to the ancient Greeks' (pp. 6-7). Now, given Greece's 'captivity in the golden prison of a classical ideal', op-ed writers seeking facile parallels may all too easily be tempted to recommend that her inhabitants take a leaf out of Socrates, Plato or Aristotle's book, but 'at the end of the day[,] none of them had anything to say about housing-market bubbles or bank failures, quantitative easing or credit-default swaps' (p. 7).

In her introductory chapter, 'Champions of the West', Hanink guides us through some of the complexities of the 2015 'Greek crisis' and its portrayal, both within Greece, and in the Western media. Wryly, she notes that 'the persistent cultural ubiquity of ancient Greece ... means that the public has a much more vivid, if distorted, idea of "Greece" than of other financially unstable countries that have recently suffered economic crises. However famous Wagner's Ring Cycle and Marvel's superhero Thor may be amongst certain demographics, the cast of Old Norse mythology did not grace nearly as many headlines when Iceland's three largest banks defaulted in 2008' (p. 24).

This ubiquity, and Greece's perceived role in shaping the roots of Western civilisation, can ultimately lead to the modern Greeks being demonised for failing to live up to their classical past, or for having allegedly allowed themselves to be infected by 'Byzantine' habits of sloth and corruption under Ottoman rule. This attitude is perhaps most shockingly revealed in former French President Valéry Giscard d'Estaing's contention, commenting on Greece's entry into the Eurozone in a 2011 interview with Germany's premier news magazine Der Spiegel: "To be perfectly frank, it was a mistake to accept Greece. Greece simply wasn't ready. Greece is basically an Oriental country"' (p. 28). In this context, Hanink argues - both at this point, and in her 'Epilogue: a note for educators' (pp. 272-8) - that the Greek ideal as it stands is 'untenable', and its death 'overdue' (p. 31).

Hanink's second chapter, 'How Athens built its brand', is perhaps one of the most insightful and tellinglyargued sections in the book, drawing as it does on Hanink's previous research on the construction and idealisation of ancient Athenians' self-image during the classical period.(2) Ranging from the adventures of Bill and Ted to the Aeneid to the 9/11 Memorial in New York, she challenges the prevalent picture of ancient Athens as 'a peaceful city of marble temples and civilised philosophical conversation' (with slaves almost entirely airbrushed out of the picture), whilst ancient Rome is unfairly damned in comparison as nothing more than a brutal empire run on slave labour. In fact, she suggests that Athens was arguably just as imperialist (if rather less geographically ambitious), and Rome just as cultured (as the Aeneid itself proves).

Rather, subsequent ages have eagerly swallowed an idealised propagandistic version of the city, created by her inhabitants through grandiose Periclean building programmes and the calculated 'staging' of empire and Athenian exceptionalism through the tragedies and ceremonies performed at the Great Dionysia. All of this constitutes what Hanink terms Athens' 'national brand', which was designed to convince other Greek citystates that Athens was unique, and that the rest of Greece therefore owed her both a pecuniary tribute and a symbolic debt. The idea that Athens had not only saved Greece from the 'barbarian' Persians and that she was the home of all the arts, but also that she was the product of exceptional ancestors whom present-day Athenians would never be able to surpass, quickly became commonplace; thus, Hanink claims convincingly that 'the idea that Athens [or Greece] just isn't what it used to be is a trope as old as the Parthenon' (p. 37).

The following chapter, 'Colonisers of an antique land', charts the beginnings of modern disillusionment with Greece, investigating those travellers in search of antiquity who flocked to the Greek lands from the beginning of the 17th century onwards (although such disappointment with modern Greece could also be found in the Roman Empire, or even in the medieval Islamic caliphates). Travellers ranging from emissaries of the Ottoman court to English gentlemen 'Dilettanti' created Greece in their own image through their travel-writing, with the Europeans often acting in a quasi-colonial fashion towards the supposedly 'degenerate' modern Greeks, treating them with a disdain fuelled ultimately by ideas found in ancient texts by authors such as Demosthenes and Plutarch. Looting of antiquities could therefore be rationalised as 'salvaging' valuable artefacts from ignorant and barbarous locals - a form of rhetoric which arguably still 
colours some modern Western sensibilities when it comes to heritage.

In chapter four, 'From state of mind to nation-state', Hanink then traces the emergence of the idea of the 'classical debt' in its modern form, distilling the complex process of its genesis into three concurrent developments:

1. European scholars invented the impossible fantasy of the "Greek ideal", ostensibly the ancient Greek aesthetic but really an ideal of ancient Greece itself.

2. A Romantic notion took hold that contemporary Greeks were descendants of the ancients who had invented and lived that ideal.

3. Greek independence came to be seen as the first essential step toward widespread revival of the ancient spirit. (p. 106)

In this reading, Europe owed 'mother Greece' for providing her with a matchless cultural heritage - and Western philhellenes would often be prepared to pay over the odds in recompense, as exemplified by the 'independence loans' of several hundred thousand pounds which were brokered in London during the Greek War of Independence, and on which the government of the First Hellenic Republic defaulted in 1828. Hanink here provides us with six brief case-studies of great philhellenes for whom the Greek ideal (in various guises) represented the pinnacle of human striving: Johann Joachim Winckelmann, Friedrich August Wolf, Adamantios Koraïs, Rigas Velestinlis, Lord Elgin, and Lord Byron.

Chapter five, 'Greek miracle 2.0', then takes us on a breathtakingly swift whistle-stop tour of the subsequent century-and-a-half of Greek history, demonstrating the ways in which the Greeks have shaped their modern identity to fit the mould of ancient fantasy in European minds - 'embracing and enacting' classicism (p. 150). Highlights include the Bavarian-sponsored transfer of the Greek capital from Nafplio to Athens under King Otto I, which led to the city's being rebuilt in classicising style, and the ensuing 'purification' and restoration of the Akropolis, in order to 'project a European fantasy of classicism onto the city' (p. 156). The rise of the racialist theories of Jakob Philipp Fallmerayer during the mid-19th century also inspired Greeks to create new counter-narratives which did not depend upon the idea of a supposed racial continuity between the inhabitants of ancient and modern Greece, but which stressed instead the previously neglected virtues of Byzantine history and its 'Helleno-Christian' legacy.

We then touch upon the so-called 'currant crisis' of 1893, which led to the Greek state's being declared bankrupt just three years before Athens hosted the first modern Olympic Games in 1896. After a brief consideration of the genesis of the (now incredibly prevalent) notion that democracy is the West's supreme 'inheritance' from Greece in a Cold War context, the chapter finally closes with a return to the Olympics: apparently Athens lost out to Atlanta in her bid for the 1996 centenary games not least because Greek representatives overplayed the 'classical debt' card during the cities' inevitable wrangling for Olympic supremacy. The Greeks themselves preferred to believe that their failure to secure a successful bid was due to the Coca-Cola company's corruption of due process - a not wholly unreasonable assumption, given the vested interests involved.

In chapter six, 'Classical debt in crisis', Hanink presents us with austerity as morality play - posing the question of whether a large enough financial debt could ever erase the supposed ancient debt in the minds of Western Europeans. Western news outlets still frame reports on Greece in recognisably Winckelmannian terms, often covering the economic crisis in an unforgivably chauvinist fashion. The apogee of this attempt to denigrate the modern Greeks for not living up to the West's ideal fantasy of the ancients can be found in a February 2010 issue of the German magazine FOCUS, which castigated the modern Greeks as " indolent sloths, cheats and liars, masters of corruption, unworthy descendants of their glorious Hellenic past"' (p. 203).(3) Hanink criticises the utter clichés which appear in the media in this context time and time again: 'Greek tragedy', Greece as the European Union's 'Achilles heel', and so forth (this section is especially 
richly illustrated with relevant cartoons and other images from the press). Instead of buying into this cheap rhetoric, she urges us to

... imagine the uproar that would ensue if a mainstream British television host haughtily mocked a politician from India for an infelicitous reference to an ancient Sanskrit epic, or if an Economist columnist punctuated a critique of Latin American politics with insinuations that the Peruvian people are shoddy excuses for Incas. What James Angelos called the West's bipolar stance toward Greece - the idea that ancient Greece belongs to the West, even if today's Greek people do not - has had the strange effect of keeping the Greeks fair game for the kind of jokes that in other cases simply would not be tolerated. (p. 221)

Perhaps the most damning indictment of Western susceptibility to such classical clichés is the response of former Greek Finance Minister Yanis Varoufakis to Hanink's query about his constant use of classical allusion in writings and speeches aimed at the West: "Rhetoric is a weapon," he acknowledged noncommittally, and its purpose is to "hit a nerve". With foreign audiences the classical references tend to play well, and the ancient metaphors are "efficient and effective"' (p. 237).

Finally, the concluding chapter, 'We are all Greeks?', touches upon some of the more toxic uses to which 'Greek myths' of racial continuity have been put in Greece over the last few years. The migrant crisis has given the so-called 'continuity thesis' a new and troubling lease of life among members of the neo-Nazi Golden Dawn party and other far-right movements, who use such ideas as a mainstay of their anti-immigrant rhetoric. The Battle of Salamis is now seen as a model for resisting other, far more recent, perceived seaborne 'invasions'. Even more disturbingly, a police roundup of c. 6,500 immigrants in summer 2012 was codenamed 'Xenios Zeus' - 'Zeus, god of strangers and guest-friendship' - a ploy which, even if not deliberately intended in irony, still appears deeply distasteful. Yet, at the same time, the West continues to chastise Greece for not preserving its ancient heritage 'properly' - thus revealing the ever more fraught triangular relationship between the West, classical antiquity, and modern Greece, which sadly still has the power to shape not only current attitudes, but also concrete fiscal and governmental policy.

As with any broadbrush work of popular history, one can always raise minor quibbles related to one's own area of expertise. For instance, as a scholar with a particular interest in German philhellenism, I felt that more attention could perhaps have been paid to the non-classicising elements of European support for the Greek War of Independence. At a time when authoritarian governments throughout the German and Habsburg lands saw support for Greek national independence as potentially seditious, and gravely curtailed the liberty of individuals and groups which promoted this cause, Greek self-determination was seen as a fitting proxy for European liberals' long-desired freedom from the dead hand of absolutism.(4) In the Teutonic lands at least, this strand of thought was arguably just as important as any idealisation of antiquity in causing citizens to lend their wholehearted support to the Greek cause, such that the designation of someone as a 'Philhellene' in German often fails to possess the Hellenising connotations which one would tend to ascribe to the term in English. However, when writing a book of this type, such generalisations or omissions are a practical (or even a rhetorical) necessity, and to portray them as a serious flaw would be highly ungenerous. (5) What truly matters is that the book in question can be enjoyed by the expert and the layman alike, albeit on differing levels - which is undoubtedly the case here. 
In sum, although The Classical Debt could hardly be the fruit of years of meticulous and painstaking scholarship, given the topical and highly contemporary nature of much of its subject matter, it is generally stylish and superlatively readable - a triumph of popularisation which can be read and reread with the greatest of pleasure, as well as providing a fruitful starting-point for more detailed surveys. Recently, Hanink was involved in a heated media debate about whether classical scholars, and female authors in particular, should be writing 'big books'.(6) Is this a 'big' book? Well, it's certainly an excellent book; intelligent, audacious, and thought-provoking. And surely that is precisely the kind of book we need - especially in these turbulent times.

\section{Notes}

1. cf. Helen Roche, review of History, Time, and Economic Crisis in Central Greece / Mussolini's Greek Island: Fascism and the Italian Occupation of Syros in World War II, (review no. 1962) < http://www.history.ac.uk/reviews/review/1962 [2]><accessed 3 July 2017>.Back to (1)

2. Johanna Hanink, Lycurgan Athens and the Making of Classical Tragedy (Cambridge, 2014).Back to (2)

3. Quotation from George Zarkadakis, 'Modern Greece's Real Problem? Ancient Greece', Washington Post, 4 November 2011. For further observations on German media coverage of the crisis in this context, see Helen Roche, 'Germany's tyranny over Greece? The philhellenist Roots of the Current Financial Crisis', History Today, 26 August 2015 (fully illustrated and referenced version available at $<$ https://archivetales.com/2015/08/27/germanys-tyranny-over-greece-the-philhellenist-roots-of-thecurrent-financial-crisis/ [3]> [accessed 3 July 2017]); also 'A love-hate relationship? The impact of historical philhellenism on Germany's view of the "Greek Crisis", unpublished paper, presented at the Taylor Institution, University of Oxford, as part of a workshop entitled 'Renegotiating history in light of the "Greek Crisis", 16 March 2016 (podcast available at < http://podcasts.ox.ac.uk/series/renegotiations-history-light-greek-crisis [4]> [accessed 3 July 2017]). Back to (3)

4. For more on this, see e.g. Wilhelm Müller und der Philhellenismus, ed. Marco Hillemann and Tobias Roth (Berlin, 2015); also more generally Helen Roche, 'The peculiarities of German Philhellenism', The Historical Journal <https://doi.org/10.1017/S0018246X17000322 [5]> [accessed 3 February 2018].Back to (4)

5. On a similar note, the fact that the book contains no comprehensive bibliography, just a short discursive section entitled 'further reading' (pp. 307-15), along with the rather sparse footnotes, can make things difficult for readers who wish to follow up specific references. For instance, I was fascinated by an allusion to the short-lived 'Greek College' (1699-1705) which George Wheler founded to host students from Greece at Gloucester Hall, Oxford (p. 86), or by the suggestion that King Otto I had harboured neo-Periclean ambitions (p. 154), and was correspondingly frustrated not to find any footnotes pertaining to these particular sections of the text. Nevertheless, this fascination is itself a testament to the skill and energy with which Hanink tells her story, transmuting the baser metal of hinted heartbreak (cf. pp. ix-xiv) into a veritable treasure-hoard of historical insight.Back to (5)

6. cf. e.g. Johanna Hanink, 'Why don't more women write "big books"?', The Chronicle of Higher Education, 2 April 2017 <http://www.chronicle.com/article/Why-Don-t-More-Women-Write/239627 [6]> [accessed 3 July 2017].Back to (6)

The author is pleased to accept this review without any further comment.

Source URL:https://reviews.history.ac.uk/review/2145

\section{Links}

[1] https://reviews.history.ac.uk/item/278160 [2] http://www.history.ac.uk/reviews/review/1962

[3] https://archivetales.com/2015/08/27/germanys-tyranny-over-greece-the-philhellenist-roots-of-the-currentfinancial-crisis/ 
[4] http://podcasts.ox.ac.uk/series/renegotiations-history-light-greek-crisis

[5] https://doi.org/10.1017/S0018246X17000322 [6] http://www.chronicle.com/article/Why-Don-t-MoreWomen-Write/239627 